spread all over Africa, pushing the Bushman south and giving rise to the Hottentots. The black race, still unaffected by $A$ and $B$, moved south, following Bushmen and Hottentot and followed by other races with all the groups, who affected the black left behind in West Africa and the rearguard.
The Bantu are thus the result of the interactions between the Caucasoid and a primitive black race showing little or no $A$ and $B$. Serologically they are more primitive than the Bushman, while if the Hottentot has had any effect it is only in recent times.

\title{
Excavations of the Egypt Exploration Society in Nubia, 1936-37
}

$\mathrm{A}^{\mathrm{N}}$ $\mathbf{N}$ exhibition of archæological finds by expeditions sent out by the Egypt Exploration Society at Tell el-Amarna and Sesebi on the Upper Nile in Nubia in the season 1936-37 opened in the rooms of the Palestine Exploration Fund, 2 Hinde Street, Manchester Square, London, W.1, on July 5, and will remain open until July 24.

The excavations in Nubia, which have been carried out under the direction in the field of Prof. A. M. Blackman, were undertaken in view of the approaching termination of the Society's operations at Tell el-Amarna, and in the expectation of obtaining a view of the culture of that period at an angle differing from that of the Amarna evidence. Sulb and Sesebi, sites covered by the concession granted to the Society by the Government of the Anglo-Egyptian Sudan, have been known since 1908 to be associated with Akhenaten, when the late J. H. Breasted identified Sesebi with the Nubian Gem-Aten, and recognized that the founder of the temple there had been Akhenaten, and not, as previously supposed, Sethos I, who had covered the inscriptions of the earlier king with plaster and inscribed on them his own name and a rededication of the temple.

Although the official name of the city was doubtless changed after the time of Akhenaten, the former name must have been retained among the people, as it was still known by that name seven centuries later, when the god of the place was recorded as "Amun of Gem-Aten".

The temple was founded about 1370 B.c., before Amenophis IV had changed his name to Akhenaten, as is shown by the foundation deposits. This change took place about the fourth year of his reign, or at Sesebi, owing to its remote situation, perhaps a little later. Scarabs of Tethmosis III and Tethmosis IV from the cemetery suggest that Sesebi was an Egyptian settlement of some importance long before the accession of Amenophis IV.

The fortified town of Sesebi is situated between the Second and 'Third Cataracts of the Nile, about one hundred and eighty miles south of Halfa. The fortress, which lies about two hundred metres distant from the river on the west bank, enclosed an area of about two hundred and seventy metres long by about two hundred metres broad. Its crude brick walls are about $4.60 \mathrm{~m}$. thick, and in some places still stand to a height of $4-5 \mathrm{~m}$. The width of the buttresses is approximately $3 \cdot 15 \mathrm{~m}$. and they stand out $2.65 \mathrm{~m}$. from the walls. In each of the four walls is a well-constructed gateway.

Within the walls, the most striking feature is a group of three temples, before excavation thought to be one only, erected on a single and unusually solid substructure, and extending along the western side of a forecourt, once enclosed in massive walls. Four sets of foundation deposits were found intact under the north-west and south-west corners of the sub. structure. They comprised among other relics two inscribed blue faience plaques and a large inscribed scarab of the same material, clearly showing that the foundation had taken place before the monarch's change of name. The full significance of this fact was brought out by reliefs on the walls of a subterranean crypt below the central temple, in which the king, sometimes with the queen, is represented seated in the company of various deities. The reliefs, therefore, belong to his polytheistic period, before he changed his religion to the monotheistic worship of the Aten. They are in the ordinary style of the Eighteenth Dynasty and not that of the Amarna period.

The crypt is in itself a remarkable discovery. It is the only known example of such a substructure at so early a date, preceding the well-known crypt of the Ptolemaic temple of Denderah by approximately thirteen hundred years.

What are conjectured to be portions of the sandstone façade of the temple, showing some highly finished reliefs, were found. Of these one shows the head of the goddess Hathor, while on another are the heads of two negro prisoners, possibly part of a much larger war relief, to which belonged a representation of the king slaying captives, not brought to England. The style of this block, with the strongly marked features and masterly line, closely resembles that of the magnificent scenes in the tomb of Horemheb. It is probably to be assigned to the end of the Eighteenth Dynasty. Mention may also be made here of a remarkable head of a granite statue of a king, or possibly of Queen Hatshepsut.

Outside the temple area an important find was a stone structure situated close to the north-east corner, which had undergone at least one recon. struction. In its original form it had been a small colonnaded open court on a stone platform about $11.70 \mathrm{~m}$. square and two metres high. This had been the work of Akhenaten, and possibly was a small sun temple, a view supported by the unusual feature that it was approached by a ramp or stairway on the western side, which would enable the officiating priest to greet the rising sun on entering the temple at dawn.

Immediately south of the temple were found three rows of magazines, and south of these again the south-western portion of the residential area. In the magazines a doorjamb inscribed to a vizir of the reign of Amenophis II supports the earlier dating of the settlement.

Although the area of the town examined had been much disturbed, it produced a quantity of interesting material. It has been possible to make out the symmetrical rectangular.planning of the streets. 
To the west of the town lies the Now Kingdom cemetery, which seems to have been subjected to considerable depredation. Tombs had been plundered, re-used and plundered again. Nevertheless, it supplied a fine collection of scarabs and much pottery, as well as other objects. Three groups included bronze mirrors laid on the chest, one a very fine specimen, and with another was a bronze bowl. A remarkable example of fine work is a green felspar amulet in the form of a baboon with the moon-disk on its head, and probably from the same string was a millefiore bead in the original gold mount. In one tomb the face painted on the cartonnage has survived. One exhibit of no little interest, though late in date, is a human pelvis still wrapped in its leather loin-cloth.

\section{Association of Technical Institutions}

\section{Summer Meeting at Blackpool}

\begin{abstract}
THE summer meeting of the Association of Technical Institutions was held at Blackpool on June 24-26.
\end{abstract}

Two reports having a direct bearing on policy were presented and discussed. The first was the report on policy in technical education, prepared by, a joint committee of the Association of Technical Institutions, the Association of Principals of Technical Institutions, the Association of Teachers in Technical Institutions and the National Society of Art Masters. First published in 1932, this report has been twice revised, in 1934-35 and in the form presented to the recent Conference. Its field is wide and includes descriptions of the present system, courses of instruction, regional co-ordination of technical education, examinations, scholarships, libraries, staffing, technical education in small towns, buildings and equipment and social activities. The second report dealt with Education for Citizenship in Technical Institutions and is dealt with in the leading article in this issue of NATURE.

of special and immediate interest was a paper on education in industrial management prepared by Mr. E. S. Byng, vice-chairman of Standard Telephones and Cables, Ltd., and Mr. G. A. Robinson, principal of the South-East London Technical Institute. This branch of education has grown considerably of late years both in Great Britain and in the United States, and its importance cannot be underestimated. As one expert has put it: "Such training was not to be a substitute for experience. .. The growing complexity of industrial organizations, the evolution of new techniques, the application of science to industry, the growing size of business units and such items as industrial, economic and technological factors combine to make successful management far more complicated and difficult than it was in the past. Experience plus training are recognized in all professions civil and military. Is management the only profession where training is unnecessary?" The social significance of the subject was well expressed by the authors of the paper when they said: "One of the greatest services which education in regard to management could render would be to imbue the general body of workers with a sound elementary knowledge of the principles affecting the conditions, conduct and direction of the undertaking which they serve. In a democracy, an understanding of the principles by the workers would assist management, whereas in a dictatorship the conditions may be different."

The authors further brought out the vast increase in the number of persons who are now concerned in management. Modern manufacturing methods actually require a much larger proportion of administrative workers than was necessary under earlier conditions. In a typical engineering organization with approximately 10,000 employees, those engaged in one phase or other of management may represent as much as twenty-five per cent of the total staff. It is not to be wondered at, therefore, that many of those in control of industry feel the need for a constant supply of young men not only proficient in the technology of departmental functions, but also trained in the principles of administration. Appendices to the paper included a list of schools where instruction in management is given, and syllabuses of "Fundamentals of Industrial Adminis. tration", "Workshop Organization and Management", and "Works Supervisory Course".

Dr. E. Benson, headmaster of the Blackpool Grammar School, read a paper on "The Grammar Schools and Technical Education". He admitted that he approached the subject from the point of view of the grammar schools. During the discussion, it was made clear that technical educationists, while differing sometimes with the educational views put forward by those connected with grammar schools, have no quarrel with grammar schools and their work as such. At the same time, they spoke their minds with some freedom when they thought the grammar schools were claiming a kind of monopoly in educational powers. Dr. Benson quoted Sir Josiah Stamp's saying that education to-day might be considered to have three main objects. It trains individuals to get a living, to live a life and to mould a world-in other words, it is education for work, leisure and responsibility. Dr. Benson's claim that the grammar school "does its best to give this complete education" may be true; but there are not lacking many who would challenge it. Neither are there lacking many who would demand to hear much more argument before they could be convinced that none of the types of post-primary schools "has succeeded so far in sharing with the grammar schools the most important of the vital qualities which the grammar schools possess. . . "The same people would probably think that Dr. Benson had only appreciated a part of the work when to that remark he added ". . except that junior technical schools, especially in conjunction with senior technical institutions, have, although they are comparatively few in number, established high standards for example in accuracy and craftsmanship". 